\title{
A polymer-supported diacetatobis(2-quinolylbenzimidazole)copper(II) complex as an efficient catalyst for oxidation of alcohols with tert-butyl hydroperoxide
}

\author{
M. L. Shilpa • V. Gayathri
}

Received: 11 August 2012/Accepted: 15 October 2012/Published online: 7 November 2012

(C) Springer Science+Business Media Dordrecht 2012

\begin{abstract}
A polymer-supported diacetatobis(2-quinolylbenzimidazole)copper(II) complex [PS-(QBIM $\left.)_{2} \mathrm{Cu}(\mathrm{II})\right]$ was synthesized by functionalization of chloromethylated polystyrene cross-linked with $6.5 \%$ divinyl benzene with 2-(2'-quinolyl)benzimidazole and subsequent treatment with $\mathrm{Cu}(\mathrm{OAc})_{2}$ in methanol. The complex was characterized by physical, analytical and spectroscopic techniques. Electronic and ESR spectra, together with magnetic susceptibility measurements, indicated that the complex was paramagnetic with distorted octahedral geometry around the copper. The complex was found to be active toward oxidation of various alcohols including phenol, benzyl alcohol and cyclohexanol using $70 \%$ aqueous tert-butyl hydroperoxide under mild conditions. Under the optimized reaction conditions, cyclohexanol gave $100 \%$ conversion to cyclohexanone, benzyl alcohol gave $98 \%$ yield of benzaldehyde and phenol gave $89 \%$ yield of catechol and $4 \%$ of hydroquinone. The complex was recycled five times without much loss in catalytic activity.
\end{abstract}

\section{Introduction}

Selective oxidation of alcohols to aldehydes is considered to be a significant transformation in organic chemistry with recognized industrial importance. Such oxidations catalyzed by transition metal complexes are of importance in biological and industrial processes. A diverse variety of copper metalloenzymes are known, including azurins [1], laccases [2] and plastocyanins [3], which are involved in

M. L. Shilpa · V. Gayathri $(\bowtie)$

Department of Studies in Chemistry, Central College Campus,

Bangalore University, Bangalore 560 001, India

e-mail: gayathritvr@yahoo.co.in electron transfer reactions. Ascorbate oxidases [4] are used as oxidizing enzymes, while hemocyanins $[5,6]$ are copper-containing oxygen transport proteins found in arthropods and mollusks. In industry, the transition metalcatalyzed reactions are used to produce value-added oxygenated compounds [7].

Recovery and reusability of a catalyst can be simplified by supporting it on an insoluble support. Chloromethylated polystyrene cross-linked with divinylbenzene is one of the most widely employed macromolecular supports for immobilization of homogeneous catalysts. These polymersupported complexes have received considerable attention due to their potential advantages over homogeneous analogues [8]. This presents a rapidly expanding research area providing advantages such as easy handling, product separation and catalyst recovery. Such catalysts can be effective for the oxidation of a wide range of organic compounds including olefins and allylic alcohols [9-11], alkyl aromatic compounds [12], sulfides [13,14] and alcohols [15, 16].

Copper complexes have been reported to be active under both homogeneous and heterogeneous conditions [17-19]. Aiming to avoid all the disadvantages of the traditional chromium reagents which cause serious environment pollution [20], many new methods for the catalytic oxidation of alcohols have been reported. In addition to the metalbased oxidizing agents, oxidants such as $\mathrm{H}_{2} \mathrm{O}_{2}, \mathrm{O}_{2}$ and tertiary butyl hydroperoxide (TBHP) are the most preferred oxidants for laboratory and industrial reactions.

Selective oxidation of benzaldehyde is important for the production of chlorine-free benzaldehyde required in the perfume and pharmaceutical industries [21]. The applicability of polymer-supported $\mathrm{Cu}$ (II) complexes as catalysts in the degradation of phenol is innovative [22]. Though oxidation of phenol using unsupported metal complexes has been reported [23], its oxidation using polymer-supported 
transition metal complexes was found to be high in the presence of TBHP [24].

In continuation of our work on polymer-supported metal complexes, we now report the synthesis and characterization of a polymer-supported $\mathrm{Cu}(\mathrm{II})$ complex of $2-\left(2^{\prime}-\right.$ quinolyl)benzimidazole and its catalytic potential for the oxidation of industrially important substrates using TBHP as oxidant. The effects of various experimental parameters have been investigated in order to optimize the reaction conditions.

\section{Experimental}

Materials and methods

Chloromethylated polystyrene divinyl benzene copolymer with $6.5 \%$ cross-linking (PS-DVB), obtained as a gift from Thermax Ltd, Pune, India, was used as a support for anchoring the metal complex. LR-grade solvents were purified according to the literature methods before use [25]. Analytical-grade copper acetate and TBHP were purchased from Merck and used as such. 2-Methyl-1-phenyl-2-propyl hydroperoxide (MPPH) was prepared according to a literature method [26]. Elemental analyses were obtained with an ELEMENTAR Vario Micro Cube CHNS analyzer. Surface area measurements by the Brunauer-Emmett-Teller (BET) method were carried out using a Micromeritics surface area analyzer model ASAP 2020. Thermogravimetric analyses were carried out using a TA Instrument, SDT analyzer model Q 600 under nitrogen atmosphere with a heating rate of $10{ }^{\circ} \mathrm{C} / \mathrm{min}$. Copper content was determined using a PerkinElmer model Atomic absorption spectrometer, after the digestion of the polymer-supported catalyst with concentrated $\mathrm{H}_{2} \mathrm{SO}_{4}$ and subsequent decomposition with $\mathrm{H}_{2} \mathrm{O}_{2}$. IR spectra in the range $400-4,000 \mathrm{~cm}^{-1}$ were recorded as $\mathrm{KBr}$ disks on a Shimadzu 8,400s FTIR spectrometer. Diffuse reflectance spectra were recorded as $\mathrm{BaSO}_{4}$ disks on a Shimadzu UV-Vis-NIR model UV-3101P spectrophotometer having an integrating sphere attachment for the solid samples. Magnetic moments of the supported and unsupported complexes were determined at room temperature using Guoy's method. ESR spectra were recorded using a Bruker EMX X-band ESR spectrometer at liquid nitrogen temperature. All the reaction products were analyzed using a Shimadzu 14B gas chromatograph fitted with flame ionization detector connected to a BP-5 capillary column.

\section{Preparation of $\left[\mathrm{Cu}(\mathrm{OAc})_{2}(\mathrm{QBIMH})_{2}\right]$}

2-(2'-quinolyl)benzimidazole was prepared according to the literature method [27]. A solution of $\mathrm{Cu}(\mathrm{OAc})_{2}(0.10 \mathrm{~g}$, $0.5 \mathrm{mmol})$ in methanol $(10 \mathrm{~mL})$ was added to a stirred solution of 2-(2'-quinolyl)benzimidazole $(0.25 \mathrm{~g}, 1.0 \mathrm{mmol})$ in $\mathrm{MeOH}(10 \mathrm{~mL})$. The mixture was refluxed for about $7 \mathrm{~h}$ on a water bath during which the brown precipitate separated out. The precipitate was filtered off, washed with ethanol and then dried under vacuum (Yield $=0.16 \mathrm{~g}, 51 \%$ ).

Functionalization of polymer support with 2-(2'-quinolyl)benzimidazole

Chloromethylated polystyrene beads cross-linked with $6.5 \%$ divinyl benzene $(5.12 \mathrm{mmol} \mathrm{Cl} / \mathrm{g})$ were washed with a mixture of THF:water in the ratio 4:1 using a Soxhlet extractor, then dried. The beads $(1.0 \mathrm{~g})$ were allowed to swell in DMF $(10 \mathrm{~mL})$ for $2 \mathrm{~h}$. A solution of QBIMH $(1.65 \mathrm{~g}, 6.73 \mathrm{mmol})$ in DMF $(20 \mathrm{~mL})$ was added to the above suspension, followed by triethylamine $(3.0 \mathrm{~g}, 4 \mathrm{~mL}$, $30 \mathrm{mmol})$ in ethyl acetate $(35 \mathrm{~mL})$, and the mixture was heated at $60{ }^{\circ} \mathrm{C}$ for $45 \mathrm{~h}$. After cooling to room temperature, the functionalized beads were filtered off, washed with ethanol, Soxhlet extracted with ethanol to remove any unreacted QBIMH, dried in an oven at $100{ }^{\circ} \mathrm{C}$ for $24 \mathrm{~h}$ and finally vacuum dried.

Preparation of the polymer-bound complex

QBIM functionalized polymer $(1.0 \mathrm{~g}, 4.4 \% \mathrm{~N})$ was soaked in toluene and acetonitrile mixture $(50 \mathrm{~mL}, 1: 1)$ for $1 \mathrm{~h}$. A solution of copper(II) acetate $(0.10 \mathrm{~g}, 0.5 \mathrm{mmol})$ in methanol $(5 \mathrm{~mL})$ was added, and the mixture was heated for $48 \mathrm{~h}$ at
Fig. 1 Preparation of the PS-(QBIM) $)_{2} \mathrm{Cu}(\mathrm{II})$ complex

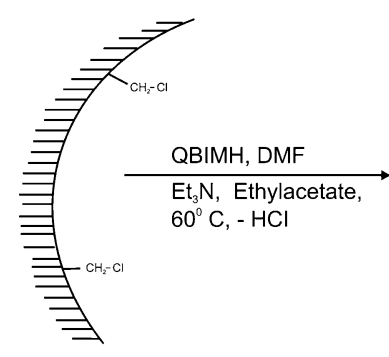

Polymer Support (PS-DVB)

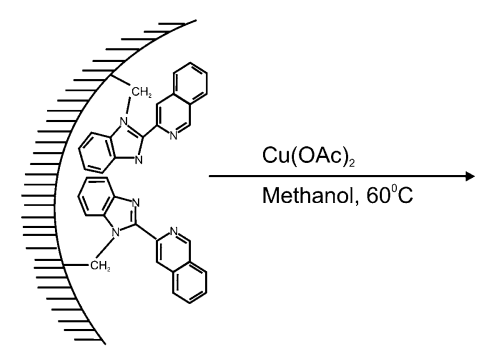

Functionalised PS-DVB

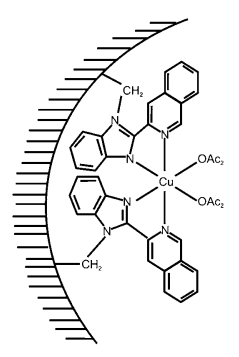

PS-(QBIM) ${ }_{2} \mathrm{Cu}$ (II) complex 
$60{ }^{\circ} \mathrm{C}$, where upon the beads turned green in color. They were then filtered off, washed with alcohol, and Soxhlet extracted with alcohol to remove excess of copper(II) acetate, dried in an oven for $24 \mathrm{~h}$ and finally vacuum dried (Fig. 1).

\section{Catalytic oxidation reactions}

In a typical reaction, a mixture of substrate $(5.0 \mathrm{mmol})$ and $70 \%$ TBHP in water $(5.0 \mathrm{mmol})$ plus acetonitrile $(10 \mathrm{~mL})$ was heated at $60{ }^{\circ} \mathrm{C}$ with stirring for $10 \mathrm{~min}$. The catalyst $(0.02 \mathrm{mmol})$ was then added to initiate the reaction. The progress of the reaction was monitored using a Shimadzu 14B gas chromatograph with FID detector and a BP-5 capillary column. After the completion of the reaction, the catalyst was filtered off and the products were analyzed.

\section{Results and discussion}

Characterization of the polymer-bound complex

PS-DVB was functionalized with 2-(2'-quinolyl)benzimidazole. Elemental analysis showed that the functionalized beads had $4.4 \%$ of nitrogen content, indicating that the QBIM was bonded to the polymer support. Copper(II) acetate was anchored to the functionalized beads and metal estimation by AAS indicated $2.3 \%$ of $\mathrm{Cu}$ in the immobilized $\mathrm{Cu}$ (II) catalyst (Fig. 1). Surface area, pore volume and pore diameter were determined by BET, and the values obtained, along with apparent bulk density, and elemental analysis are given in Table 1. Decrease in the surface area, pore volume and pore diameter after functionalization and anchoring of the metal may be due to blocking of the pores on the surface of the polymer beads. Slight increase in the bulk density of the support is observed after functionalization and anchoring of the metal complex. The unsupported complex was prepared by reacting $\mathrm{Cu}(\mathrm{II})$ acetate and QBIMH in 1:2 mole ratio in methanol and analyzed for the formula $\mathrm{Cu}(\mathrm{OAc})_{2}$ $(\mathrm{QBIMH})_{2}$.

Swelling studies were carried out in order to study the interaction of the polymer support with various solvents, which in turn influences the rate of the catalytic reaction. Percentage swellings of the polymer beads and the PS$(\mathrm{QBIM})_{2} \mathrm{Cu}(\mathrm{II})$ complex in different solvents are given in Table 2. The maximum swelling occurred in acetonitrile for the supported complex; hence, acetonitrile was chosen as the solvent for the oxidation reactions.

The IR spectra of the polymer support (A), functionalized beads (B), functionalized beads with copper(II) acetate (C), recycled beads (D) and the free complex $\mathrm{Cu}(\mathrm{OAc})_{2}(\mathrm{QBIMH})_{2}$ (E) were recorded in the region $4,000-400 \mathrm{~cm}^{-1}$ (Fig. 2). The IR spectrum of the chloromethylated polystyrene beads exhibited peaks at 1,265 and $829 \mathrm{~cm}^{-1}$ due to $v_{\mathrm{CH}_{2}-\mathrm{Cl}}$ and $v_{\mathrm{C}-\mathrm{Cl}}$. On functionalization, these peaks decreased in intensity, consistent with the bonding of QBIM onto the polymer support. The free QBIMH exhibited a peak around $3,400 \mathrm{~cm}^{-1}$ due to $\mathrm{v}_{\mathrm{N}-\mathrm{H}}$ which was absent in the functionalized polymer, indicating that the ligand has been attached through the nitrogen onto the polymer beads.

The functionalized beads exhibited a peak at $1,624 \mathrm{~cm}^{-1}$ due to $v_{\mathrm{C}=\mathrm{N}}$ which was shifted to $1,614 \mathrm{~cm}^{-1}$ for the anchored beads, indicating that the nitrogens of the pyridine and benzimidazole moieties of the ligand are coordinated to copper. The anchored beads displayed peaks at 1,545 and $1,438 \mathrm{~cm}^{-1}$ due to $v_{\mathrm{C}=\mathrm{O}}$ and $v_{\mathrm{C}-\mathrm{O}}$, respectively, characteristic of monodentate coordination of acetate to the copper [28]. The IR spectra of the recycled and anchored complexes were similar. The unsupported complex (E) exhibited a peak due to $v_{\mathrm{N}-\mathrm{H}}$ at $3,248 \mathrm{~cm}^{-1}$ which was absent for the polymer-supported metal complex, confirming that the 2 -(2'-quinolyl)benzimidazole is bonded through nitrogen to the polymer support.

Table 1 Physical properties and analytical data of polymer beads, functionalized beads, PS-(QBIM) $)_{2} \mathrm{Cu}(\mathrm{II})$ complex, recycled catalyst and $\mathrm{Cu}(\mathrm{OAc})_{2}(\mathrm{QBIMH})_{2}$

\begin{tabular}{|c|c|c|c|c|c|c|c|c|}
\hline \multirow[t]{2}{*}{ Parameters } & \multirow[t]{2}{*}{ Color } & \multicolumn{4}{|c|}{ Analytical data } & \multirow{2}{*}{$\begin{array}{l}\text { Apparent } \\
\text { bulk density } \\
\left(\mathrm{g} / \mathrm{cm}^{3}\right)\end{array}$} & \multirow{2}{*}{$\begin{array}{l}\text { Surface } \\
\text { area } \\
\left(\mathrm{m}^{2} / \mathrm{g}\right)\end{array}$} & \multirow{2}{*}{$\begin{array}{l}\text { Pore } \\
\text { volume } \\
(\mathrm{cc} / \mathrm{g})\end{array}$} \\
\hline & & $\mathrm{C} \%$ & $\mathrm{H} \%$ & $\mathrm{~N} \%$ & $\mathrm{Cu} \%$ & & & \\
\hline PS-DVB & White & 73.9 & 6.2 & - & - & 0.3 & 20.8 & 0.2 \\
\hline Functionalized beads with QBIM & Off white & 72.4 & 8.6 & 4.4 & - & 0.4 & 19.2 & 0.2 \\
\hline $\begin{array}{l}\text { Functionalized QBIM beads } \\
\text { anchored with } \mathrm{Cu}(\mathrm{OAc})_{2}\end{array}$ & Light green & 70.9 & 8.5 & 4.2 & 2.3 & 0.4 & 15.8 & 0.1 \\
\hline Recycled catalyst & Light green & 3.7 & 8.2 & 3.7 & 2.3 & 0.4 & 15.6 & 0.1 \\
\hline $\mathrm{Cu}(\mathrm{OAc})_{2}(\mathrm{QBIMH})_{2}^{\mathrm{a}}$ & Brown & $\begin{array}{l}64.9 \\
(64.3)\end{array}$ & $\begin{array}{l}4.0 \\
(4.2)\end{array}$ & $\begin{array}{l}12.2 \\
(12.5)\end{array}$ & $\begin{array}{l}9.5 \\
(9.4)\end{array}$ & $\begin{array}{l}- \\
-\end{array}$ & $\begin{array}{l}- \\
-\end{array}$ & - \\
\hline
\end{tabular}

${ }^{a}$ Calculated values are in parentheses 
Table 2 Swelling studies of polymer support and polymer-supported $(\mathrm{QBIM})_{2} \mathrm{Cu}(\mathrm{II})$ catalyst

\begin{tabular}{lll}
\hline Solvents & \multicolumn{2}{l}{ Swelling mole $(\%)$} \\
\cline { 2 - 3 } & PS-DVB & $\begin{array}{l}\text { PS-(QBIM) }{ }_{2} \mathrm{Cu}(\mathrm{II}) \\
\text { catalyst }\end{array}$ \\
\hline Methanol & 1.0 & 0.9 \\
Ethanol & 0.9 & 0.8 \\
Acetonitrile & 1.4 & 1.2 \\
THF & 1.2 & 0.7 \\
Benzene & 0.5 & 0.4 \\
Ethyl acetate & 0.7 & 0.5 \\
\hline
\end{tabular}

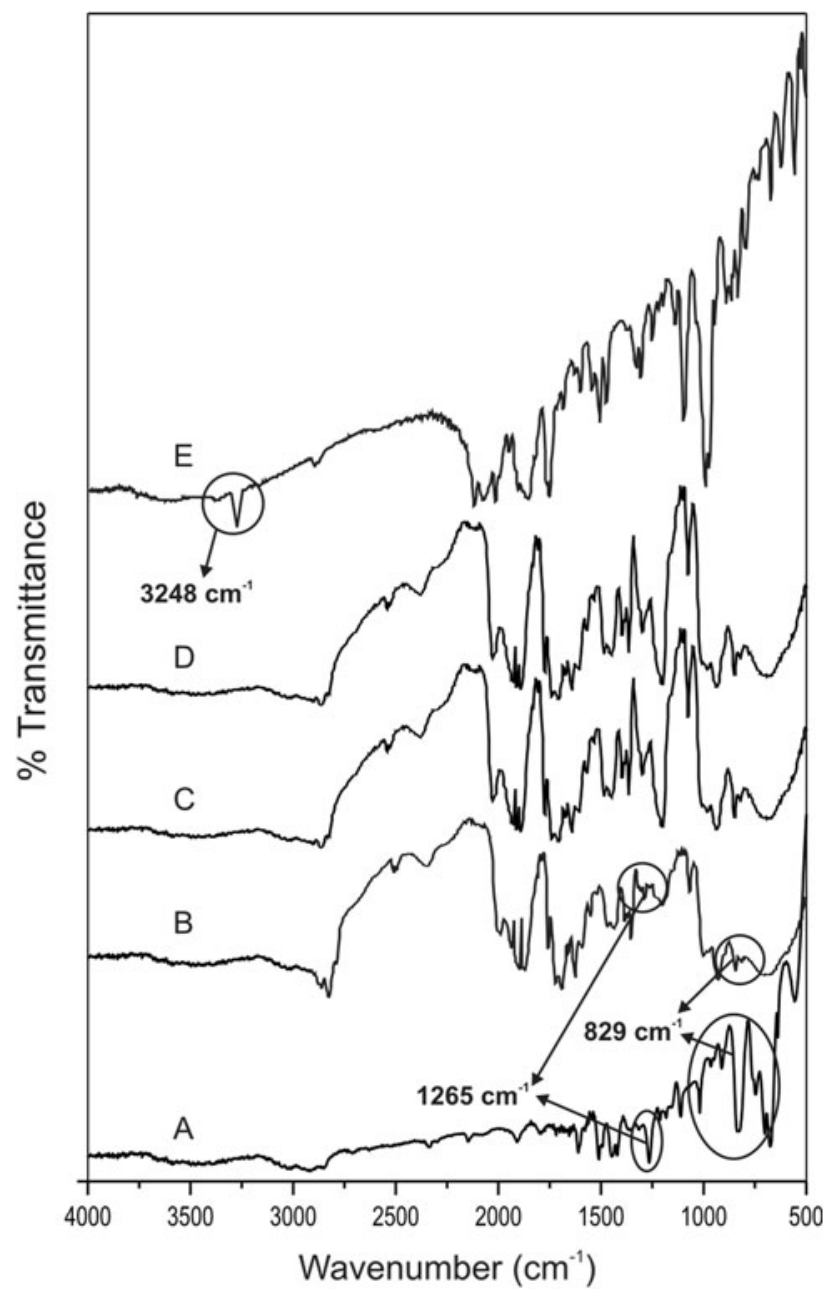

Fig. 2 Infrared spectra of $(A)$ PS-DVB, $(B)$ functionalized polymer, $(C)$ polymer-supported $\mathrm{Cu}(\mathrm{II})$ complex, $(D)$ recycled polymersupported complex and $(E) \mathrm{Cu}(\mathrm{OAc})_{2}(\mathrm{QBIMH})_{2}$

The diffuse reflectance spectra (Fig. 3) of the unsupported (A) and polymer-supported (B) copper complexes were similar. Free QBIMH exhibited absorption bands at 272, 295 and $328 \mathrm{~nm}$, assigned to $n \rightarrow \pi^{*}$ and $\pi \rightarrow \pi^{*}$ transitions. The electronic spectra of the supported and

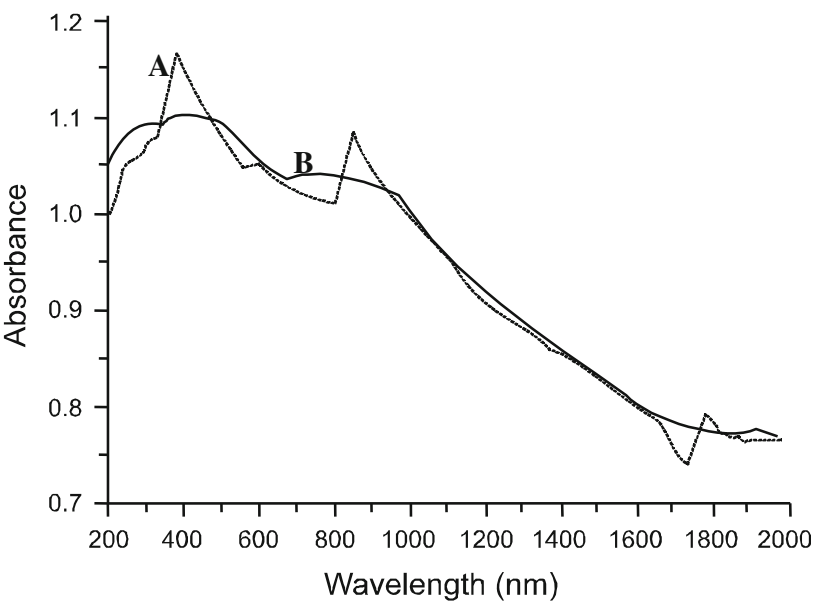

Fig. 3 Diffuse reflectance spectra of polymer-supported and unsupported complex. $A=\mathrm{Cu}(\mathrm{OAc})_{2}(\mathrm{QBIMH})_{2}$ complex, $B=$ PS-(QBIM $)_{2} \mathrm{Cu}(\mathrm{II})$ complex

unsupported complexes exhibited bands around 415, 620 and $880 \mathrm{~nm}$ assigned to ${ }^{2} \mathrm{~B}_{1 \mathrm{~g}} \rightarrow{ }^{2} \mathrm{E}_{\mathrm{g}},{ }^{2} \mathrm{~B}_{1 \mathrm{~g}} \rightarrow{ }^{2} \mathrm{~B}_{2 \mathrm{~g}}$ and ${ }^{2} \mathrm{~B}_{1 \mathrm{~g}} \rightarrow{ }^{2} \mathrm{~A}_{1 \mathrm{~g}}$ transitions [29], consistent with a $\mathrm{d}^{9}$ configuration of $\mathrm{Cu}$ (II) with distorted octahedral geometry.

The magnetic moments of the polymer-supported and unsupported complexes at room temperature were found to be 2.06 and $2.14 \mathrm{BM}$, respectively. The ESR spectra of the $\mathrm{Cu}(\mathrm{OAc})_{2}(\mathrm{QBIMH})_{2}$ and $\mathrm{PS}-(\mathrm{QBIM})_{2} \mathrm{Cu}$ (II) complexes at liquid nitrogen temperature exhibited two peaks and the calculated $g \perp$ and $g \|$ values for both the complexes were around 2.10 and 2.35, respectively. The magnetic moments and ESR spectral studies are therefore also consistent with the presence of copper(II).

The thermal stabilities of the polymer support and the anchored complex were studied under a nitrogen atmosphere with heating rate of $10^{\circ} \mathrm{C} / \mathrm{min}$ up to $600{ }^{\circ} \mathrm{C}$. Thermogravimetric analysis indicated that the polymer support was stable up to $330{ }^{\circ} \mathrm{C}$. The stability of the supported complex was decreased, being stable up to $270{ }^{\circ} \mathrm{C}$.

\section{Effect of solvents}

In order to study the effect of solvent on the reaction, several solvents $(10 \mathrm{~mL})$ were employed for the oxidation of different substrates $(5.0 \mathrm{mmol})$ [cyclohexanol, benzyl alcohol and phenol] with TBHP $(5.0 \mathrm{mmol})$ at $60{ }^{\circ} \mathrm{C}$. The maximum conversion of substrates was obtained in acetonitrile (Table 3), which may be due to the polarity of solvent and also the solubilities of the reactants. To check whether the reaction was progressing or stopped due to decomposition, the reaction was carried out for substrates with $1: 1$ substrate/TBHP ratio at $60{ }^{\circ} \mathrm{C}$ for $12 \mathrm{~h}$ in benzene. Under these conditions, the conversion was 72,49 and $54 \%$ for phenol, cyclohexanol and benzyl alcohol, 
Table 3 Effect of solvents on the oxidation of alcohols

\begin{tabular}{lclllll}
\hline Substrates & \multicolumn{2}{l}{$\%$ conversion in different solvents } & & & \\
\cline { 2 - 6 } & Acetonitrile & Methanol & Ethanol & THF & Ethyl acetate & Benzene \\
\hline Phenol & 98 & 70 & 57 & 80 & 85 & 29 \\
Cyclohexanol & 100 & 78 & 59 & 86 & 70 & 35 \\
Benzyl alcohol & 98 & 78 & 69 & 56 & 49 & 34 \\
\hline
\end{tabular}

respectively, showing that the reaction was still ongoing but slower in non-polar solvents compared to polar solvents. Hence, we selected acetonitrile as solvent for our oxidation reactions.

\section{Catalytic oxidation of alcohols}

The catalytic activity of the polymer-supported complex was investigated for the oxidation of phenol, benzyl alcohol and cyclohexanol at $60{ }^{\circ} \mathrm{C}$ using both $\mathrm{H}_{2} \mathrm{O}_{2}$ and TBHP as oxidants (Scheme 1). When $\mathrm{H}_{2} \mathrm{O}_{2}$ was used as oxidant, the catalyst decomposed and the product formation was low. Hence, TBHP was chosen as the oxidant for further catalytic studies. Since $\mathrm{Cu}(\mathrm{OAc})_{2}(\mathrm{QBIMH})_{2}$ was insoluble in most common organic solvents including acetonitrile, its catalytic activity was not screened. The catalytic reactions were carried out by varying the catalyst and substrate concentration, reaction temperature and substrate to TBHP ratio.

The oxidation of phenol with $0.02 \mathrm{mmol}$ of the catalyst using TBHP as oxidant at $60{ }^{\circ} \mathrm{C}$ in acetonitrile gave catechol and hydroquinone as the major and minor products, respectively. Several reaction parameters were varied in order to identify the most suitable conditions for maximum

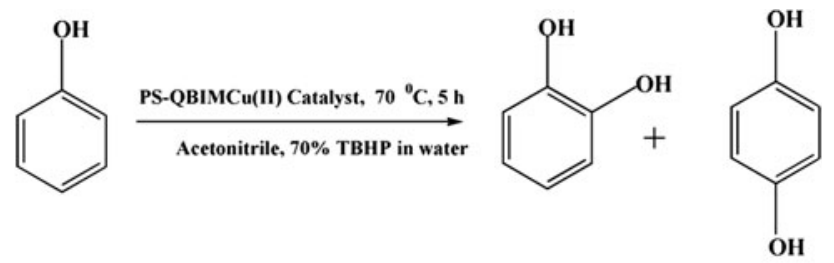<smiles>CC(C)(C)COC(=O)c1ccccc1C=O</smiles>

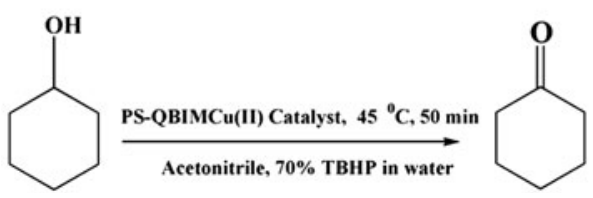

Scheme 1 Oxidation of various alcohols catalytic activity and product selectivity. The results are given in Table 4.

For catalyst concentrations between 0.01 and $0.05 \mathrm{mmol}$, the conversion of phenol to catechol (89\%) was optimum when $0.02 \mathrm{mmol}$ of catalyst was used, while conversion was reduced at higher catalyst concentrations (entries 3-5). Hence, $0.02 \mathrm{mmol}$ catalyst was chosen for further catalytic studies. At lower substrate concentration (2.5 mmol) with 1:1 substrate/TBHP ratio, the formation of catechol was $87 \%$ (entry 9) and hydroquinone was not formed. On increasing the phenol concentration to $10 \mathrm{mmol}$, the formation of catechol slightly decreased (entry 11). For $7.5 \mathrm{mmol}$ of the substrate concentration, the conversion of phenol was higher than for $10.0 \mathrm{mmol}$ of the substrate. To study the influence of the temperature on the conversion, reactions were carried out at 30, 45, 60 and $70{ }^{\circ} \mathrm{C}$ (entries 6, 7, 2 and 8). The \% conversion of phenol was low at lower temperatures but higher at $70{ }^{\circ} \mathrm{C}$, with the formation of catechol and hydroquinone in 89 and $6 \%$ yields, respectively (entry 8). At 1:2 ratio of substrate/ TBHP, the conversion of phenol was $99 \%$, with maximum formation of catechol ( $89 \%$, entry 18). Hence, the optimized reaction conditions for the oxidation of phenol were $0.02 \mathrm{mmol}$ of catalyst with $7.5 \mathrm{mmol}$ of phenol, using $1: 2$ phenol to TBHP ratio at $70{ }^{\circ} \mathrm{C}$ in $10 \mathrm{~mL}$ of acetonitrile (entry 18). The plot of conversion of phenol under the optimized reaction conditions is shown in Fig. 4. The turnover frequency of the catalyst under these conditions was $94 / \mathrm{h}$ with formation of $89 \%$ catechol and $4 \%$ hydroquinone. At $225 \mathrm{~min}$, the conversion of phenol was around $50 \%$. After $5 \mathrm{~h}$ of the reaction, the conversion of phenol remained almost constant. The formation of hydroquinone was negligible at the beginning of the reaction; its formation increased to $4 \%$ after $3 \mathrm{~h}$ and then decreased.

\section{Reaction mechanism}

Oxidation reactions catalyzed by transition metal complexes using TBHP as an oxidant can proceed by either homolytic or heterolytic decomposition of the alkyl hydroperoxide [30]. The present oxidation was carried out using 50 equivalents of 2,6-di-t-butyl-4-methyl phenol (BHT) with $0.02 \mathrm{mmol}$ of the PS-(QBIM) $)_{2} \mathrm{Cu}$ (II) catalyst 
Table 4 Effect of catalyst and substrate concentration, substrate/TBHP ratio, temperature, reaction time on the oxidation of phenol

\begin{tabular}{|c|c|c|c|c|c|c|c|c|}
\hline Entry & $\begin{array}{l}\text { Catalyst } \\
\text { conc. } \\
(\mathrm{mmol})\end{array}$ & $\begin{array}{l}\text { Temp } \\
\left({ }^{\circ} \mathrm{C}\right)\end{array}$ & $\begin{array}{l}\text { Phenol conc. } \\
\text { (mmol) }\end{array}$ & $\begin{array}{l}\text { Substrate/ } \\
\text { TBHP ratio }\end{array}$ & $\begin{array}{l}\text { Reaction } \\
\text { time (h) }\end{array}$ & $\begin{array}{l}\% \text { Unreacted } \\
\text { phenol }\end{array}$ & $\%$ Catechol & $\%$ Hydroquinone \\
\hline 1 & 0.01 & 60 & 5.0 & $1: 1$ & 6 & 25 & 49 & 13 \\
\hline 2 & 0.02 & 60 & 5.0 & $1: 1$ & 6 & 5 & 85 & 8 \\
\hline 3 & 0.03 & 60 & 5.0 & $1: 1$ & 6 & 5 & 81 & 8 \\
\hline 4 & 0.04 & 60 & 5.0 & $1: 1$ & 6 & 5 & 80 & 8 \\
\hline 5 & 0.05 & 60 & 5.0 & $1: 1$ & 6 & 4 & 77 & 7 \\
\hline 6 & 0.02 & 30 & 5.0 & $1: 1$ & 6 & 47 & 40 & 10 \\
\hline 7 & 0.02 & 45 & 5.0 & $1: 1$ & 6 & 27 & 52 & 15 \\
\hline 8 & 0.02 & 70 & 5.0 & $1: 1$ & 6 & 4 & 89 & 6 \\
\hline 9 & 0.02 & 70 & 2.5 & $1: 1$ & 6 & 3 & 87 & - \\
\hline 10 & 0.02 & 70 & 7.5 & $1: 1$ & 6 & 3 & 87 & 4 \\
\hline 11 & 0.02 & 70 & 10.0 & $1: 1$ & 6 & 20 & 74 & 3 \\
\hline 12 & 0.02 & 70 & 10.0 & $1: 1$ & 10 & 8 & 75 & 6 \\
\hline 13 & 0.02 & 70 & 10.0 & $1: 1$ & $24 \mathrm{~h}$ & 6 & 75 & 8 \\
\hline 14 & 0.02 & 70 & 7.5 & $1: 1$ & 5 & 8 & 59 & 11 \\
\hline 15 & 0.02 & 70 & 7.5 & $1: 1$ & 4 & 13 & 49 & 13 \\
\hline 16 & 0.02 & 70 & 7.5 & $1: 1$ & 8 & 4 & 87 & 5 \\
\hline 17 & 0.02 & 70 & 7.5 & $1: 0.5$ & 6 & 26 & 57 & 9 \\
\hline 18 & 0.02 & 70 & 7.5 & $1: 2$ & 6 & 1 & 89 & 4 \\
\hline 19 & 0.02 & 70 & 5.0 & $1: 0.5$ & 6 & 12 & 80 & 5 \\
\hline 20 & 0.02 & 70 & 5.0 & $1: 2$ & 6 & 3 & 90 & 3 \\
\hline
\end{tabular}

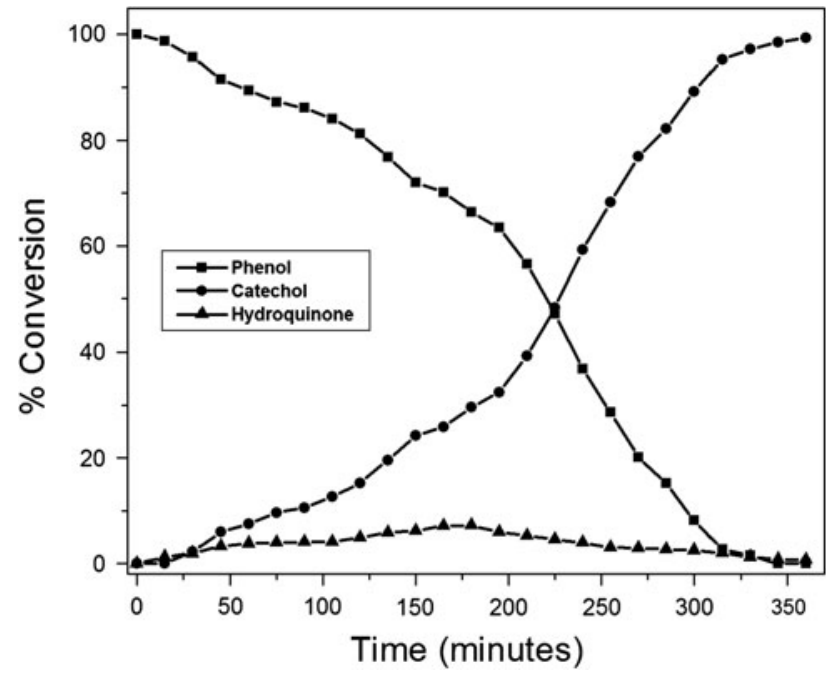

Fig. 4 Plot of $\%$ conversion of phenol versus time. Reaction conditions: $0.02 \mathrm{mmol}$ of PS-(QBIM) $)_{2} \mathrm{Cu}$ (II) catalyst, $7.5 \mathrm{mmol}$ of phenol with $1: 2$ substrate/TBHP ratio at $70{ }^{\circ} \mathrm{C}$ in $10 \mathrm{~mL}$ acetonitrile

plus $7.5 \mathrm{mmol}$ of phenol in $10 \mathrm{~mL}$ of acetonitrile in the presence of TBHP (Substrate/TBHP $=1: 2$ ) at $70{ }^{\circ} \mathrm{C}$. BHT is a scavenger for free peroxy radicals. The results showed that there was no change in the conversion of phenol and formation of the reaction products compared to the optimized reaction conditions.

The oxidation of phenol under the optimized reaction conditions was also carried out using methyl-1-phenyl-2propyl hydroperoxide (MPPH) as a mechanistic probe, to check for the homolytic versus heterolytic scission of the peroxide $\mathrm{O}-\mathrm{O}$ bond. According to Sorokin et al. [31], if the reaction proceeds via heterolytic cleavage of the $\mathrm{O}-\mathrm{O}$ bond, then the reaction with MPPH and the catalyst should give 2-methyl-1-phenyl-2-propanol. On the other hand, homolytic cleavage of the hydroperoxide leads to a radical mechanism yielding acetone, benzyl alcohol and benzaldehyde as some of the $\beta$-scission products.

The reaction was carried out using MPPH (1.66 g) and catalyst $(0.01 \mathrm{mmol})$ in acetonitrile $(10 \mathrm{~mL})$ for $5 \mathrm{~h}$ and the reaction products analyzed by GC revealed the presence of 2-methyl-1-phenyl-2-propanol. Under the same reaction conditions, when phenol was used as the substrate, the product analysis showed the presence of catechol, hydroquinone, unreacted phenol and 2-methyl-1-phenyl-2-propanol. Thus, in this case, no products arising from the homolytic cleavage of MPPH were detected [32], and we conclude that the oxidation of phenol occurs by the heterolytic cleavage of the $\mathrm{O}-\mathrm{O}$ bond of hydroperoxide; a plausible mechanism for this catalytic system is shown in Fig. 5. 


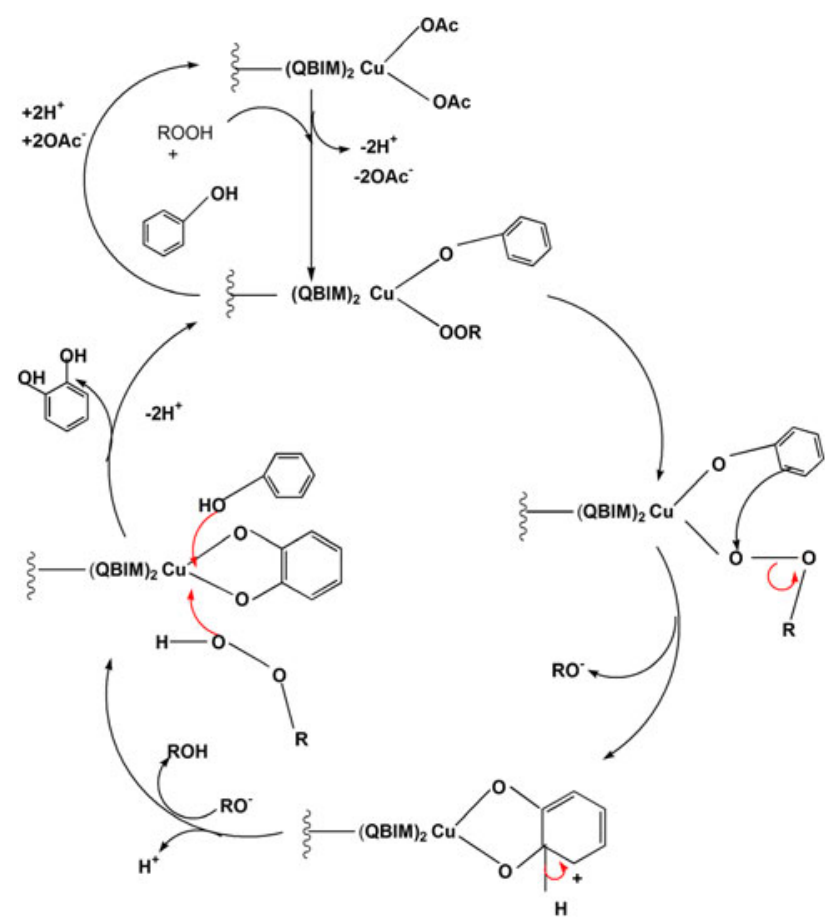

Fig. 5 Plausible mechanism for the oxidation of phenol by PS- $(\mathrm{QBIM})_{2} \mathrm{Cu}(\mathrm{II})$ complex
Oxidation of benzyl alcohol and cyclohexanol

Oxidations of benzyl alcohol and cyclohexanol were carried out in acetonitrile with 1:2 substrate/TBHP ratio to give benzaldehyde and cyclohexanone, respectively. Thus, benzyl alcohol was selectively oxidized to benzaldehyde with only a trace amount of benzoic acid. The optimized conditions for the oxidation of benzyl alcohol to benzaldehyde were found to be $0.02 \mathrm{mmol}$ of catalyst and $15.0 \mathrm{mmol}$ of substrate with $1: 1$ substrate/TBHP ratio at $50{ }^{\circ} \mathrm{C}$ (entry 12). When the reaction was carried out for $3 \mathrm{~h}$, there was $98 \%$ conversion of benzyl alcohol, with $98 \%$ of benzaldehyde formation (Table 5). When the optimized reaction was continued for $24 \mathrm{~h}$ (entry 19), slight formation of benzoic acid was observed (5\%) along with $95 \%$ benzaldehyde. The turnover frequency for the oxidation of benzyl alcohol was 250/h.

Oxidation of cyclohexanol gave $100 \%$ cyclohexanone as the product in $50 \mathrm{~min}$ (Table 6). The optimized reaction conditions were $0.02 \mathrm{mmol}$ of catalyst and $25.0 \mathrm{mmol}$ of cyclohexanol with $1: 1$ substrate/TBHP ratio at $45^{\circ} \mathrm{C}$ (entry 13). The turnover frequency was $2,500 / \mathrm{h}$ with $100 \%$ conversion of cyclohexanol. Comparison of the catalytic activity of PS-(QBIM) ${ }_{2} \mathrm{Cu}$ (II) with other reported systems (Table 7) reveals that the present system exhibits superior catalytic activity [8, 21, 33, 34].

Table 5 Effect of catalyst, substrate concentration, temperature, time, substrate/TBHP ratio on the oxidation of benzyl alcohol in $10 \mathrm{~mL}$ acetonitrile

\begin{tabular}{|c|c|c|c|c|c|c|c|}
\hline Entry & $\begin{array}{l}\text { Catalyst concentration } \\
(\mathrm{mmol})\end{array}$ & $\begin{array}{l}\text { Temperature } \\
\left({ }^{\circ} \mathrm{C}\right)\end{array}$ & $\begin{array}{l}\text { Reaction } \\
\text { time (h) }\end{array}$ & $\begin{array}{l}\text { Benzyl alcohol } \\
\text { concentration (mmol) }\end{array}$ & $\begin{array}{l}\text { Substrate/ } \\
\text { TBHP ratio }\end{array}$ & $\begin{array}{l}\% \text { Unreacted } \\
\text { benzyl alcohol }\end{array}$ & $\%$ benzaldehyde \\
\hline 1 & 0.01 & 60 & 3 & 5.0 & $1: 1$ & 21 & 76 \\
\hline 2 & 0.02 & 60 & 3 & 5.0 & $1: 1$ & 6 & 94 \\
\hline 3 & 0.03 & 60 & 3 & 5.0 & $1: 1$ & 11 & 88 \\
\hline 4 & 0.02 & 30 & 3 & 5.0 & $1: 1$ & 34 & 66 \\
\hline 5 & 0.02 & 45 & 3 & 5.0 & $1: 1$ & 13 & 87 \\
\hline 6 & 0.02 & 50 & 3 & 5.0 & $1: 1$ & 5 & 94 \\
\hline 7 & 0.02 & 60 & 3 & 5.0 & $1: 1$ & 6 & 92 \\
\hline 8 & 0.02 & 70 & 3 & 5.0 & $1: 1$ & 9 & 89 \\
\hline 9 & 0.02 & 50 & 3 & 2.5 & $1: 1$ & 5 & 95 \\
\hline 10 & 0.02 & 50 & 3 & 7.5 & $1: 1$ & 5 & 95 \\
\hline 11 & 0.02 & 50 & 3 & 10.0 & $1: 1$ & 5 & 93 \\
\hline 12 & 0.02 & 50 & 3 & 15.0 & $1: 1$ & 2 & 98 \\
\hline 13 & 0.02 & 50 & 3 & 20.0 & $1: 1$ & 11 & 87 \\
\hline 14 & 0.02 & 50 & 8 & 20.0 & $1: 1$ & 9 & 88 \\
\hline 15 & 0.02 & 50 & $90 \mathrm{~min}$ & 15.0 & $1: 1$ & 64 & 35 \\
\hline 16 & 0.02 & 50 & 2 & 15.0 & $1: 1$ & 19 & 80 \\
\hline 17 & 0.02 & 50 & 3 & 15.0 & $1: 2$ & 5 & 94 \\
\hline 18 & 0.02 & 50 & 3 & 15.0 & $1: 0.5$ & 15 & 84 \\
\hline 19 & 0.02 & 50 & $24 \mathrm{~h}$ & 15.0 & $1: 1$ & 1 & 95 \\
\hline
\end{tabular}


Table 6 Effect of catalyst, substrate concentration, temperature, time, substrate/TBHP ratio on the oxidation of cyclohexanol in $10 \mathrm{~mL}$ acetonitrile

\begin{tabular}{|c|c|c|c|c|c|c|c|}
\hline Entry & $\begin{array}{l}\text { Catalyst concentration } \\
(\mathrm{mmol})\end{array}$ & $\begin{array}{l}\text { Temperature } \\
\left({ }^{\circ} \mathrm{C}\right)\end{array}$ & $\begin{array}{l}\text { Reaction time } \\
(\min )\end{array}$ & $\begin{array}{l}\text { Cyclohexanol } \\
\text { concentration (mmol) }\end{array}$ & $\begin{array}{l}\text { Substrate/ } \\
\text { TBHP ratio }\end{array}$ & $\begin{array}{l}\% \text { Unreacted } \\
\text { cyclohexanol }\end{array}$ & $\%$ Cyclohexanone \\
\hline 1 & 0.01 & 60 & 50 & 5.0 & $1: 1$ & 44 & 55 \\
\hline 2 & 0.02 & 60 & 50 & 5.0 & $1: 1$ & 0 & 100 \\
\hline 3 & 0.03 & 60 & 50 & 5.0 & $1: 1$ & 0 & 100 \\
\hline 4 & 0.02 & 30 & 50 & 5.0 & $1: 1$ & 28 & 70 \\
\hline 5 & 0.02 & 45 & 50 & 5.0 & $1: 1$ & 0 & 100 \\
\hline 6 & 0.02 & 45 & 25 & 5.0 & $1: 1$ & 67 & 31 \\
\hline 7 & 0.02 & 45 & 40 & 5.0 & $1: 1$ & 31 & 68 \\
\hline 8 & 0.02 & 45 & $24 \mathrm{~h}$ & 5.0 & $1: 1$ & 0 & 100 \\
\hline 9 & 0.02 & 45 & 50 & 2.5 & $1: 1$ & 0 & 100 \\
\hline 10 & 0.02 & 45 & 50 & 10.0 & $1: 1$ & 0 & 100 \\
\hline 11 & 0.02 & 45 & 50 & 15.0 & $1: 1$ & 0 & 100 \\
\hline 12 & 0.02 & 45 & 50 & 20.0 & $1: 1$ & 0 & 100 \\
\hline 13 & 0.02 & 45 & 50 & 25.0 & $1: 1$ & 0 & 100 \\
\hline 14 & 0.02 & 45 & 50 & 30.0 & $1: 1$ & 14 & 86 \\
\hline 15 & 0.02 & 45 & 300 & 30.0 & $1: 1$ & 13 & 87 \\
\hline 16 & 0.02 & 45 & 420 & 30.0 & $1: 1$ & 12 & 88 \\
\hline 17 & 0.02 & 45 & 50 & 25.0 & $1: 0.5$ & 43 & 56 \\
\hline 18 & 0.02 & 45 & 50 & 25.0 & $1: 2$ & 0 & 100 \\
\hline 19 & 0.02 & 45 & 50 & 5.0 & $1: 0.5$ & 33 & 67 \\
\hline 20 & 0.02 & 45 & 50 & 5.0 & $1: 2$ & 0 & 100 \\
\hline
\end{tabular}

Table 7 Comparison of the catalytic activity of PS-(QBIM) $)_{2} \mathrm{Cu}(\mathrm{II})$ complex with other reported systems

\begin{tabular}{|c|c|c|c|c|c|}
\hline Catalyst & Oxidant & $\begin{array}{l}\text { Temperature } \\
\left({ }^{\circ} \mathrm{C}\right)\end{array}$ & $\begin{array}{l}\text { Time } \\
\text { (h) }\end{array}$ & $\begin{array}{l}\% \text { Conversion } \\
\text { of phenol }\end{array}$ & Ref \\
\hline \multicolumn{6}{|l|}{ Phenol } \\
\hline PS- $-(\mathrm{QBIM})_{2} \mathrm{Cu}(\mathrm{II})$ complex & TBHP & 70 & 5 & 99 & This work \\
\hline$(\mathrm{P}-\mathrm{HPHZ}-\mathrm{Cu})^{\mathrm{a}}$ & $\mathrm{H}_{2} \mathrm{O}_{2}$ & 70 & 24 & 45 & [33] \\
\hline$(\mathrm{P}-\mathrm{HPPn}-\mathrm{Cu})^{\mathrm{b}}$ & $\mathrm{H}_{2} \mathrm{O}_{2}$ & 70 & 24 & 53 & {$[34]$} \\
\hline Catalyst & Oxidant & $\begin{array}{l}\text { Temperature } \\
\left({ }^{\circ} \mathrm{C}\right)\end{array}$ & $\begin{array}{l}\text { Time } \\
\text { (h) }\end{array}$ & $\begin{array}{l}\% \text { Conversion } \\
\text { of cyclohexanol }\end{array}$ & Ref \\
\hline \multicolumn{6}{|l|}{ Cyclohexanol } \\
\hline PS- $(\mathrm{QBIM})_{2} \mathrm{Cu}$ (II) complex & ТВHP & 45 & $50 \mathrm{~min}$ & 100 & This work \\
\hline $\begin{array}{l}8 \% \text { poly }(\mathrm{S}-\mathrm{DVB}) \mathrm{L}-\mathrm{val} \\
\mathrm{Cu}(\mathrm{II}) \text { complex }\end{array}$ & ТВHP & 45 & $24 \mathrm{~h}$ & 25 & {$[21]$} \\
\hline Catalyst & Oxidant & $\begin{array}{l}\text { Temperature } \\
\left({ }^{\circ} \mathrm{C}\right)\end{array}$ & $\begin{array}{l}\text { Time } \\
\text { (h) }\end{array}$ & $\begin{array}{l}\% \text { Conversion } \\
\text { of benzyl alcohol }\end{array}$ & Ref \\
\hline \multicolumn{6}{|l|}{ Benzyl alcohol } \\
\hline PS-(QBIM $)_{2} \mathrm{Cu}(\mathrm{II})$ complex & TBHP & 50 & 3 & 98 & This work \\
\hline$[\mathrm{PS}-\mathrm{Cu}-\mathrm{TSC}]$ catalyst $^{\mathrm{c}}$ & $\mathrm{H}_{2} \mathrm{O}_{2}$ & 60 & 6 & 100 & {$[8]$} \\
\hline
\end{tabular}

\footnotetext{
${ }^{\mathrm{a}} \mathrm{P}-\mathrm{HPHZ}-\mathrm{M}=$ polymer-supported $\left[N, N^{\prime}\right.$-bis $(o$-hydroxy acetophenone $)$ hydrazine $]$ copper complex

${ }^{\mathrm{b}}(\mathrm{P}-\mathrm{HPPn}-\mathrm{M})=$ polymer-supported $\left[N, N^{\prime}\right.$-bis $(o$-hydroxy acetophenone) propylene diamine $]$ copper complex

${ }^{c}[\mathrm{PS}-\mathrm{Cu}-\mathrm{TSC}]=$ polymer-supported thiosemicarbazone copper(II) complex
} 
Table 8 Recycling ability of the catalyst

\begin{tabular}{llll}
\hline Number of cycles & \multicolumn{2}{l}{ \% Conversion } \\
\cline { 2 - 4 } & Phenol & Cyclohexanol & $\begin{array}{r}\text { Benzyl } \\
\text { alcohol }\end{array}$ \\
\hline I & 98 & 97 & 96 \\
II & 97 & 96 & 95 \\
III & 95 & 95 & 94 \\
IV & 95 & 93 & 93 \\
V & 93 & 91 & 94 \\
\hline
\end{tabular}

Heterogeneity and recycling tests

A heterogeneity test was performed by taking $0.02 \mathrm{mmol}$ of the catalyst plus $5.0 \mathrm{mmol}$ of cyclohexanol with a $1: 1$ substrate/TBHP ratio at $60{ }^{\circ} \mathrm{C}$ in acetonitrile. Reaction for 30 min gave $27 \%$ conversion. The catalyst was then filtered from the reaction mixture and the filtrate left stirring for another $1 \mathrm{~h}$ at $60{ }^{\circ} \mathrm{C}$. The $\mathrm{GC}$ analysis indicated that the conversion of cyclohexanol remained unchanged. The filtrate was tested for metal content by AAS. There was no metal content in the filtrate, which indicated that there was no leaching of the metal from the polymer support during the catalytic reaction and the polymer-supported complex was truly heterogeneous.

The recycling ability was tested by using $0.02 \mathrm{mmol}$ catalyst plus $5.0 \mathrm{mmol}$ of the substrates at $60{ }^{\circ} \mathrm{C}$ with $1: 1$ substrate/TBHP in acetonitrile medium. After the reaction, the catalyst was filtered off, washed with alcohol and dried before use and recycled five times. The recycling ability of the catalyst is shown in Table 8 . The catalytic activity of the supported complex toward oxidation of alcohols remained almost constant on recycling. Analytical and spectral studies of the recycled catalyst indicated that the metal did not leach out from the support and the structure of the polymer-supported complex remained unchanged even after recycling five times.

\section{Conclusion}

Chloromethylated polystyrene cross-linked with $6.5 \%$ divinyl benzene was successfully functionalized with 2-(2'-quinolyl)benzimidazole, and copper(II) acetate was anchored on it. The catalyst was active toward oxidation of alcohols using TBHP as an oxidant. The PS-(QBIM) ${ }_{2} \mathrm{Cu}(\mathrm{II})$ catalyst is recyclable, efficient, stable and can be reused without appreciable decrease in the activity. Hence, this polymer-supported complex is a prospective heterogeneous catalyst for the oxidation of various organic compounds.
The authors are presently engaged in carrying out the oxidation of other industrially important organic compounds.

Acknowledgments Authors wish to thank UGC, New Delhi, India, for Major Research Project [F no. 39-741/2010(SR)]; Department of Chemistry, Bangalore University, Bangalore, for instrumentation facilities; and Thermax Ltd., for providing PS-DVB.

\section{References}

1. Anderson GL, Williams J, Hille R (1992) J Biol Chem 267: 23674-23682

2. Suresh PS, Kumar A, Kumar R, Singh VP (2008) J Mol Graph Model 26:845-849

3. Sato K, Kohzuma T, Dennison C (2003) J Am Chem Soc 125:2101-2112

4. Boyer PD, Lardy H, Myrback K (eds) (1963) The enzymes, 2nd edn, vol 8. Academic Press, New York

5. Kitajima N, Fujisawa K, Fujimoto C, Morooka Y, Hashimoto S, Kitagawa T, Toriumi K, Tatsumi K, Nakamura A (1992) J Am Chem Soc 114:1277-1291

6. Solomon EI, Tuczek F, Root DE, Brown CA (1994) Chem Rev 94:827-856

7. Caradonna In JP, King RB (1994) Encyclopedia of inorganic chemistry, vol 6, 2nd edn. Wiley, Chichester

8. Islam M, Hossain D, Mondal P, Tuhina K, Roy AS, Mondal S, Mobarak M (2011) Trans Met Chem 36:223-230

9. Hwang JH, Abu-Omar MM (1999) Tetrahedron Lett 40: 8313-8316

10. Mohebbi S, Boghaei DM, Sarvestani AH, Salimi A (2005) Appl Catal A Gen 278:263-267

11. Conte V, Di Furia F, Licini G (1997) Appl Catal A Gen 157: 335-361

12. Battistel E, Tassinari R, Fornaroli M, Bonoldi L (2003) J Mol Catal A: Chem 202:107-115

13. Barbarini A, Maggi R, Muratori M, Sartori G, Sartorio R (2004) Tetrahedron Asymmetry 15:2467-2473

14. Smith TS, Pecoraro VL (2002) Inorg Chem 41:6754-6760

15. Hoppe E, Limberg C, Ziemer B (2006) Inorg Chem 45: 8308-8317

16. Figiel PJ, Sobczak JM, Ziolkowski JJ (2004) Chem Commun 2:244-245

17. Rothernburg G, Feldberg L, Wiener H, Sasson Y (1998) J Chem Soc Perkin Trans 2:2429-2434

18. Striegler S (2006) Tetrahedron 62:9109-9114

19. Ferguson G, Ajjou AN (2003) Tetrahedron Lett 44:9139-9142

20. Muzart J (1992) Chem Rev 92:113-140

21. Choudhary VR, Dumbre DK, Narkhede VS, Jana SK (2003) Cat Lett 86:229-233

22. Castro IU, Sherrington DC, Fortuny A, Fabregat A, Stuber F, Font J, Bengoa C (2010) Catal Today 157:66-70

23. Owsik IA, Kolarz BN, Jezierska J (2006) J Catal Lett 107: 197-203

24. Gupta KC, Sutar AK (2008) Polym Adv Technol 19:186-200

25. Perrin DD, Armanego WCF, Perrin DR (1996) Purification of laboratory chemicals, I edn. Pergamon Press, New York

26. Haitt RR, Strachan WMJ (1963) J Org Chem 28:1893-1894

27. Hisano T, Ichikawa M, Tsumoto K, Tasaki M (1982) Chem Pharm Bull 30:2996-3004

28. Wang S, Cui Y, Tan R, Luo Q, Shi J, Wu Q (1994) Polyhedron 13:1661-1668

29. Sathyanarayana DN (2001) Spectra of transition metal complexes-a survey, I edn. University press, India Ltd 
30. Valodkar VB, Tembe GL, Ravindranathan M, Ram RN, Rama HS (2004) J Mol Catal A: Chem 208:21-32

31. Sorokin AB, Mangematin S, Pergrale C (2002) J Mol Catal A: Chem 182-183:267-281

32. Yiu Shek-Man, Man Wai-Lun, Lau Tai-Chu (2008) J Am Chem Soc 130:10821-10827
33. Ishii $\mathrm{Y}$, Iwahama T, Sakaguchi S, Nakayama K, Nishiyama $\mathrm{Y}$ (1996) J Org Chem 61:4520-4526

34. Maurya MR, Arya A, Adao P, Pessoa JC (2008) Appl Catal A Gen 351:239-252 